\title{
Construction of Phage Vectors in Streptomyces: Introduction of the Thiostreptone Resistant (tsr) Gene into R4 Phage
}

\author{
Tomio Morino, ${ }^{*}$ Takao IsogaI, ${ }^{* *}$ Hideo TAKAHASHI \\ and Hiuga SAITo \\ Institute of Applied Microbiology, \\ The University of Tokyo, Bunkyo-ku, Tokyo 113, Japan
}

Received December 16, 1983

\begin{abstract}
We have constructed phage cloning vectors from an actinophage, R4. A deletion derivative (R4 $422 \mathrm{~B}$ ) which had a BamHI linker inserted at the unique PvuII site was used to clone the thiostreptone resistant $(t s r)$ gene derived from plasmid vector pIJ365. The $t s r$ derivative obtained, R4A22B-tsr1, was shown to have the same level of thiostreptone resistance in lysogenized cells as that of pIJ365-carrying cells. Under the optimal conditions, R4A22B-tsr 1 phage was lysogenized at a frequency of $5 \times 10^{-2}$ per infected phage. The usefulness of R4 phage derivatives for gene cloning is discussed.
\end{abstract}

Streptomyces strains are notable as producers of medically important antibiotics. We have been working on construction of phage vector systems in Streptomyces strains. An actinophage, R4, and its deletion mutants are useful as cloning vectors. ${ }^{1,2)}$ Also we reported construction of a restriction map of the $\mathrm{R} 4$ phage genome. ${ }^{3)}$ Although R4 phage and its deletion derivatives are quite useful for gene cloning in Streptomyces, it is desirable to add a selective marker to the $\mathrm{R} 4$ cloning vectors. In the case of coli-phage lambda, a lactose-utilizing gene (lac) has been used for this purpose. ${ }^{4)}$ Since R4 is a temperate phage, we can introduce antibiotic resistant markers into it to select the lysogens.

In this report we describe construction of a R4 phage derivative having an antibiotic resistant gene. Expression of the resistant gene in the phage and transduction of the phage are discussed.

\section{MATERIALS AND METHODS}

a) Bacterial and phage strains. Streptomyces lividans 66 and $S$. parvulus 2297 (cys) were described in a previous paper. ${ }^{5)} \mathrm{R} 4 \Delta 2$ is a deletion mutant of R4 phage. ${ }^{1)} S$. lividans TK 123 carrying pIJ 365 was kindly provided by D. A. Hopwood.

b) Media. NB medium was used for germination of spores, phage propagation, phage titration and the crossstreak test. NB medium consisted of $0.8 \%$ Nutrient broth (Difco), $5 \mathrm{~mm} \mathrm{Ca}\left(\mathrm{NO}_{3}\right)_{2}$ and $0.5 \%$ glucose. $\mathrm{NB}$ agar and NB soft agar contained $1.5 \%$ and $0.7 \%$ Bacto-agar (Difco), respectively. YS agar plates were used for spore formation and phage lysogenization. YS agar medium consisted of $0.2 \%$ Yeast extract (Difco), $1 \%$ soluble starch and $1.5 \%$ Bacto-agar (Difco) ( $\mathrm{pH} 7.0)$. Minimal agar medium was the same as described in a previous paper. ${ }^{5)}$ Thiopeptin was kindly provided by Fujisawa Pharmacerutical Co. and used for detection of thiostreptone resistance.

c) Purification of DNA, cleavage analysis and transfection. Plasmid pIJ365 was prepared by the method of IshHorowicz and Burke. ${ }^{8)}$ For restriction analysis, plasmid DNA was purified by $\mathrm{CsCl}$-ethidium bromide and sucrose density gradient centrifugation. Cleavage analysis and transfection were performed as described previously. ${ }^{3,5}$

d) Insertion of BamHI linker into the R4 phage genome. R4 phage DNA digested with PvuII endonuclease was mixed with BamHI linker (Genex Co., Ltd.) at a molecular ratio of $1: 50$ ligated with T4 DNA ligase. The ligated DNA was redigested with PvuII endonuclease to

* Present address: Laboratory of Process Development and Engineering, Nippon Kayaku Co., Ltd., Kita-ku, Tokyo, Japan.

** Present address: Research Laboratories, Fujisawa Pharmaceutical Co., Ltd., Yatabe-cho, Ibaraki 305, Japan. 
eliminate self-ligated DNA molecules. Transfection was performed using protoplasts of $S$. lividans or $S$. parvulus as the recipients. ${ }^{5}$

e) Induction of $R 4$ lysogens. About $5 \times 10^{8}$ colony forming units (c.f.u.) of R4 lysogenized spores were inoculated into $5 \mathrm{ml}$ of $\mathrm{NB}$ medium. After $6 \sim 8 \mathrm{hr}$ cultivation at $30^{\circ} \mathrm{C}$ with shaking, mitomycin $\mathrm{C}$ (Kyowa Hakko, Co.) was added to the medium to a final concentration of $10 \mu \mathrm{g} / \mathrm{ml}$. Then the cultivation was continued for a further $3 \mathrm{hr}$ and cells were removed by centrifugation at $3,000 \mathrm{rpm}$ for $10 \mathrm{~min}$. The phage lysate was filtered through a $0.22 \mu \mathrm{m}$ pore-size nitrocellulose filter.

f) Minimal inhibitory concentration (MIC) of thiopeptin. A homogenized spore suspension of about $5 \times 10^{7}$ c.f.u. per ml was prepared and $10 \mu$ of this suspension was used for spot-tests on YS agar plates containing various amounts of thiopeptin. After two days incubation at $27^{\circ} \mathrm{C}$, the growth response of the spores was examined.

\section{RESULTS AND DISCUSSION}

\section{a) Isolation of deletion mutants}

Deletion mutants of R4 phage were isolated from $\mathrm{R} 4 \Delta 2$ by a pyrophosphate enrichment method. ${ }^{1)}$ A phage suspension was treated with $25 \mathrm{~mm}$ pyrophosphate for $10 \mathrm{~min}$ at $30^{\circ} \mathrm{C}$ and surviving phages (About $10^{-2}$ ) were propagated without pyrophosphate. By repeating the pyrophosphate enrichment procedure seven times, the pyrophosphate resistance of the final phage lysate increased to $1.2 \times 10^{-1}$. Another cycle of pyrophosphate treatment was performed and then the phage lysate was subjected to single-plaque isolation. Twelve

Table I. Pyrophosphate Resistance of R4 Phage Derivatives

\begin{tabular}{llc}
\hline Strain & Deletion $(\mathrm{kb})$ & Surviving fraction $^{a}$ \\
\hline R4 wild & 0 & $1.3 \times 10^{-5}$ \\
R442 & 2.7 & $2.7 \times 10^{-2}$ \\
R4421 & $2.7+1.5$ & $1.0 \times 10^{-1}$ \\
R4A22 & $2.7+2.5$ & $2.0 \times 10^{-1}$ \\
R4422B-tsr 1 & 3.3 & $6.9 \times 10^{-2}$ \\
\hline
\end{tabular}

a Phage strains were treated with $50 \mathrm{~mm}$ sodium pyrophosphate in $50 \mathrm{~mm}$ Tris- $\mathrm{HCl}(7.5)$ at $37^{\circ} \mathrm{C}$ for 10 min. Surviving fractions were calculated from the titer before and after the treatment. R4 421 and $\mathrm{R} 4 \Delta 22$ have new $1.5 \mathrm{~kb}$ and $2.5 \mathrm{~kb}$ deletions, respectively, besides the $2.7 \mathrm{~kb}$ deletion of R $4 \Delta 2$. clones were obtained and further examined. As a result we isolated two clones which have new deletions besides the $\Delta 2$ deletion. The two deletions were named $\Delta 21$ and $\Delta 22$. Properties of the deletion mutants are summarized in Table I.

The R4 422 mutant can form plaques on $S$. parvulus but not on $S$. lividans although the phage mutant lysogenizes normally to both strains. However, the R4 421 mutant cannot lysogenize to the same strains. So the region of the $\Delta 21$ deletion is essential for the lysogenization.

\section{b) Introduction of the BamHI site into the R4 genome (Table II)}

We have previously shown that R4 phage DNA has a unique PvuII site in a dispensable region, which can be used for a cloning site. ${ }^{2)}$ The PvuII site is quite useful for inserting DNA fragments with blunt ends, but not adequate for cloning other restriction fragments. R4 phage DNA has no BamHI site. So $B a m \mathrm{HI}$ linker was introduced into the $P v u I I$ site of R4 $\Delta 2, \mathrm{R} 4 \Delta 21$ and R4 22 phage DNAs. The resultant BamHI site-bearing derivatives of these deletion mutants were named R4A2B, $\mathrm{R} 4 \Delta 21 \mathrm{~B}$ and $\mathrm{R} 4 \Delta 22 \mathrm{~B}$, respectively. The presence of the BamHI site in R4A22B is shown in Fig. 2 (lane 2) and Fig. 3 (lanes 2 and 5). The presence of BamHI sites in R4A2B and R4A21B was also confirmed by cleavage analysis (data not shown). The deletion sizes of the R4 $42 \mathrm{~B}, \mathrm{R} 4 \Delta 21 \mathrm{~B}$ and $\mathrm{R} 4 \Delta 22 \mathrm{~B}$ mutants are $2.7 \mathrm{~kb}, 4.2 \mathrm{~kb}$ and $5.2 \mathrm{~kb}$, respectively. So we can clone at least $5.2 \mathrm{~kb}$ DNA fragments with cohesive ends identical to those of the BamHI sites.

TABLE II. EFFECT OF DELEtions on Plating Efficiency

\begin{tabular}{cc}
\hline Phage strain & E.O.P. ${ }^{a}$ \\
\hline R4 wild & 0.23 \\
R4A21 & 0.14 \\
R4A22 & $<1.0 \times 10^{-8}$ \\
\hline
\end{tabular}

a Efficiency of plating (E.O.P.) signifies the ratio of E.O.P. on $S$. lividans to that on $S$. parvulus. 
c) Introduction of the tsr gene into the $R 4$ genome

To construct $\mathrm{R} 4$ phage derivatives having an antibiotic resistant gene, the thiostreptone resistant gene (tsr) of plasmid pIJ365 was introduced into the BamHI site of R4422B phage DNA. The construction is schematically illustrated in Fig. 1. R4A22B and pIJ365 DNAs which had been cleaved with BamHI endonuclease, were mixed at a molecular ratio of $1: 5$ and ligated with T4 DNA ligase. The ligated DNA was transfected to $S$. parvulus and about 300 phage clones were obtained. These clones were mixed and lysogenized to $S$. parvulus. After sporulation of the putative lysogens, spores were replica-plated on YS agar plates containing $50 \mu \mathrm{g} / \mathrm{ml}$ of thiopeptin. Seven thiopeptin resistant clones were obtained. These clones were confirmed to be R4 lysogens as phages were induced by mitomycin $\mathrm{C}$ treatment. After repeated single plaque isolation, all of the phage clones were shown to give thiopeptin resistance by their lysogenization to $S$. parvulus. One clone, named R4A22B-tsr1, was used for further characterization.

Since the R4A22B-tsr 1 phage shows a thiopeptin resistant phenotype upon lysogenization, the phage should have the $t s r$ gene. To confirm the presence of the $t s r$ gene in R4A22B-tsr 1 phage DNA, cleavage analysis of the phage DNA was performed. The results of agarose gel electrophoresis are shown in Figs. 2 and 3. As shown in lanes 2 and 3 of Fig. 2, Bam HI digests of R4A22B and R4A22B-tsr 1 DNAs gave apparently identical bands. A predicted $4.5 \mathrm{~kb}$ Bam $\mathrm{HI}$ fragment derived from pIJ365 was not observed in the BamHI digest of R4 $422 \mathrm{~B}-t s r 1$ DNA. This result suggests that the BamHI fragment containing the ts $\dot{r}$ gene was inserted into the BamHI site of R4422B and that one of the BamHI sites was deleted. This was confirmed by double digestion experiments. When the R4A22B-tsr 1 DNA was digested with BamHI and PstI, 0.72 and $5.4 \mathrm{~kb}$ fragments were observed. The smaller fragment was identical to that of pIJ365 cleaved with BamHI and PstI, and the larger

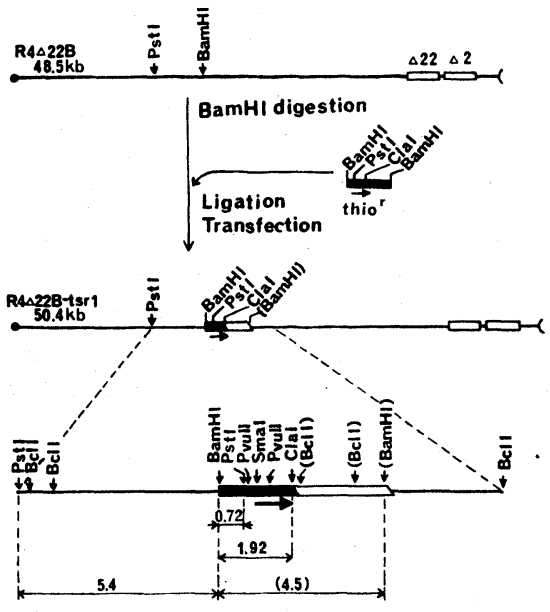

Fig. 1. Construction of the R4A22B Derivative Containing the $t s r$ Gene.

BamHI-cleaved R4422B phage DNA was ligated with BamHI-cleaved pIJ365 DNA and transfected to $S$. parvulus. Resultant transfectants were lysogenized to $S$. parvulus and thiopeptin resistant clones were obtained. One of such clones was induced and the phage obtained was named R4422B-tsr1. A BamHI DNA fragment derived from pIJ365 containing the $t s r$ gene is shown as a heavy line and an arrow. The lower part shows the restriction map of R4 $422 \mathrm{~B}-t s r 1$ phage. An open box shows a deleted region and numbers below the restriction map indicate distances between restriction sites $(\mathrm{kb})$. Restriction sites and the number in parentheses signify putative restriction sites and the size, respectively.

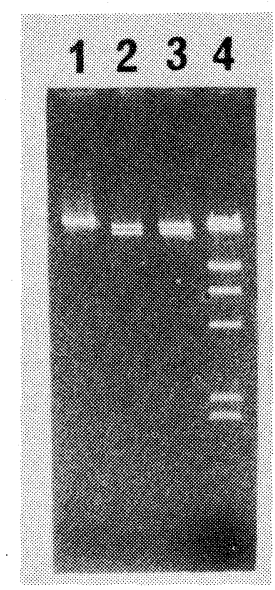

FIG. 2. Agarose Gel Analysis of R4 Derivatives.

R4 22 DNA (lane 1), R4 $422 B$ DNA (lane 2) and R4 22 B-tsr1 DNA (lane 3) were digested with BamHI restriction endonuclease and alalyzed on agarose gel. Lane 4 shows lambda DNA digested with HindIII. 


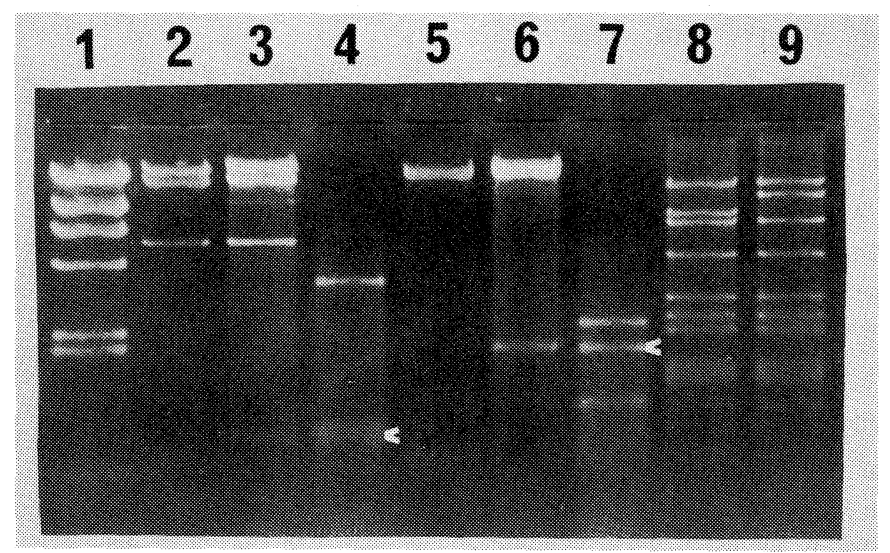

Fig. 3. Cleavage Analysis of R4A22B-tsr1 Phage DNA.

DNA was digested with restriction enzymes and the fragments were analyzed by $0.8 \%$ agarose gel electrophoresis. Lane 1, HindIII-digested lambda DNA (reference). Lane 2, BamHI-PstI-digested R4 22 B DNA. Lane 3, BamHI-PstI-digested R4422B-tsr1 DNA. Lane 4, BamHI-PstI-digested pIJ365 DNA. Lane 5, BamHI-ClaI-digested R4 422 B DNA. Lane 6, BamHI-ClaI-digested R4422B-tsr1 DNA. Lane 7, BamHIClaI-digested pIJ365 DNA. Lane 8, BclI-digested R4422B DNA. Lane 9, BclI-digested R4 $22 B-t s r 1$ DNA. Arrows in lanes 4 and 7 indicate the 0.72 and $1.92 \mathrm{~kb}$ fragments shown in Fig. 1.

Table III. EfFect of Medium and Antibiotic AdDition Time on Lysogenization FREQUENCY

\begin{tabular}{|c|c|c|}
\hline \multirow[t]{2}{*}{ Time $(\mathrm{hr})^{a}$} & \multicolumn{2}{|c|}{$\begin{array}{l}\text { Lysogenization frequency } \\
\qquad(\mathrm{CFU} / \mathrm{PFU})^{b}\end{array}$} \\
\hline & YS & MM \\
\hline 0 & $2.5 \times 10^{-5}$ & $2.5 \times 10^{-5}$ \\
\hline 2 & $7.5 \times 10^{-5}$ & $1.0 \times 10^{-3}$ \\
\hline 3 & $4.0 \times 10^{-4}$ & $3.4 \times 10^{-3}$ \\
\hline 6 & $8.5 \times 10^{-4}$ & $7.5 \times 10^{-3}$ \\
\hline 8 & $3.7 \times 10^{-3}$ & $\mathrm{ND}^{c}$ \\
\hline 14.5 & $1.5 \times 10^{-2}$ & $3.0 \times 10^{-2}$ \\
\hline 17 & $1.8 \times 10^{-2}$ & $5.4 \times 10^{-2}$ \\
\hline 20 & - & $6.0 \times 10^{-2}$ \\
\hline
\end{tabular}

a Germinated spores of $S$. parvulus were infected with $\mathrm{R} 4 \Delta 22 \mathrm{~B}-t s r 1$ at $\mathrm{m} . \mathrm{o} . \mathrm{i} .=0.1$. After $20 \mathrm{~min}$ incubation at $27^{\circ} \mathrm{C}$, infected cells were spread on YS or MM plates. At the indicated times, $3 \mathrm{ml}$ of NB soft agar containing $50 \mu \mathrm{g} / \mathrm{ml}$ thiopeptin was overlayed.

$b$ Lysogenization frequency is shown as colony forming units (c.f.u.) per phage infected (p.f.u.).

c Not determined.

fragment was identical to that of R4A22B cleaved with BamHI and PstI. Since the PstI site of R4 $22 \mathrm{~B}$ DNA is located on the lefthand side of the Bam HI site and the $5.4 \mathrm{~kb}$ BamHI-PstI fragment of R4A22B-tsr1 DNA is intact, the left-hand side of the BamHI site

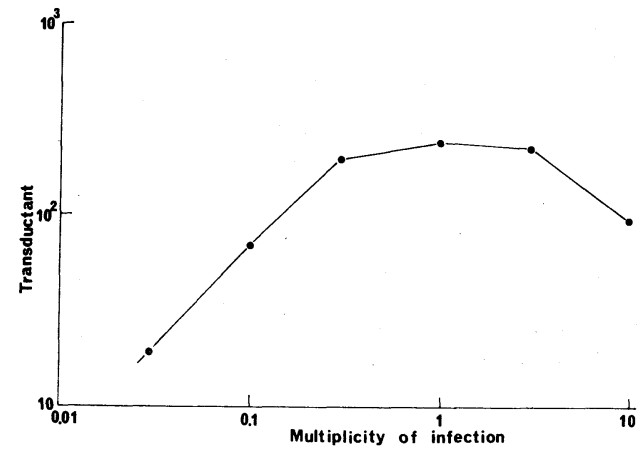

FIG. 4. Dose Response of Transductants to m.o.i. in R4 $422 \mathrm{~N}$-trs 1 Phage Infection.

Germinated spores of $S$. parvulus were infected with R4 $422 \mathrm{~B}-t s r 1$ phage at increasing m.o.i. and thiopeptin resistant clones were counted. Other conditions were the same as described in the legend to Table III.

should be intact (see Fig. 1 and lanes $2 \sim 4$ of Fig. 3). Also BamHI-ClaI digested R4422B$t s r 1 \mathrm{DNA}$ gave a $1.92 \mathrm{~kb}$ fragment identical to that of pIJ365 cleaved with BamHI and ClaI (lanes 6 and 7). R4A22B DNA has no ClaI site (lane 5). If we compare $\mathrm{Bcl}$ I-digested fragments of R4 $422 \mathrm{~B}$ and R4422B-tsr 1 DNAs, a $7.6 \mathrm{~kb}$ fragment of $\mathrm{R} 4 \triangle 22 \mathrm{~B}$ DNA increases in size to $9.5 \mathrm{~kb}$ in R4 22B-tsr 1 DNA (lanes 8 and 9). Therefore we concluded that the BamHI fragment containing the $t s r$ gene was inserted 
Table IV. Characteristics of R4 Phage Vectors

\begin{tabular}{|c|c|c|c|}
\hline Strain & Deletion(kb) & Cloning site & Comments \\
\hline $\mathrm{R} 4 \Delta 2$ & 2.7 & $P v u \mathrm{II}$ & \\
\hline $\mathrm{R} 4 \Delta 21$ & 4.2 & PvuII & $c$ I like \\
\hline $\mathrm{R} 4 \Delta 22$ & 5.2 & $P v u \mathrm{II}$ & No growth on $S$. lividans \\
\hline $\mathrm{R} 4 \Delta 2 \mathrm{~B}$ & 2.7 & BamHI & \\
\hline $\mathrm{R} 4 \Delta 21 \mathrm{~B}$ & 4.2 & BamHI & Same as $\mathrm{R} 4 \Delta 21$ \\
\hline $\mathrm{R} 4 \Delta 22 \mathrm{~B}$ & 5.2 & BamHI & Same as $\mathrm{R} 4 \Delta 22$ \\
\hline $\mathrm{R} 4 \Delta 22 \mathrm{~B}-t s r 1$ & 3.3 & BamHI, SmaI, PvuII, ClaI & $\begin{array}{l}\text { No growth on } S \text {. lividans, } t s r \text { marker, } \\
\text { insertional inactivation }(C l a \mathrm{I})\end{array}$ \\
\hline
\end{tabular}

into the BamHI iste of R4 $422 \mathrm{~B}$ and that the right-hand side of the region was deleted (Fig. 1). The deletion size was estimated to be about $1.9 \mathrm{~kb}$. So the genome size of R $4 \Delta 22 \mathrm{~B}-t s r 1$ is about $3.3 \mathrm{~kb}$ smaller than that of wildtype R4. As shown in Fig. 1, we found one PstI, one $S m c$ DNA insertion. Also two Pvull sites can Bam HI-ClaI fragment.

R4422B-tsr1 phage DNA has three unique sites, BamHI, SmaI, and ClaI, availabel for DNA insertion. also two PvuII sites can be used for gene cloning. Especially the latter three sites are in the $t s r$ gene and useful for insertional inactivation.

\section{d) Optimal conditions for R4A22B-tsrl phage lysogenization}

R4422B-tsr1 phage shows thiopeptin resistance upon lysogenization. To determine the optimal conditions for lysogenization of R4 phage, R4 222B-tsr1 phage was used. When S. parvulus 2297 was used as the recipient, poor media such as minimal medium were suitable for a high frequency of lysogenization. Maximum lysogenization was attained when the phage-infected spores were incubated for $16 \mathrm{hr}$ at $27^{\circ} \mathrm{C}$ before thiopeptin addition. The lysogenization frequency was about $5 \times 10^{-2}$ per infected phage (Table III).

Figure 4 shows that the number of thiopeptin resistant clones increases linearly with increasing M.O.I. At a high M.O.I., the frequency declined presumably due to the killing effect of infecting phages.

The lysogens were quite stable even in the absence of the drug. This will be quite impor- tant for use of the phage vector as a low copy number vector.

e) Minimal inhibitory concentration of thiopeptin for R4422B-tsrl lysogens

The minimal inhibitory concentration be MIC) of thiopeptin was examined using $S$. parvulus lysogenized with R4A22B-tsr 1 phage. The MIC was $3 \mu \mathrm{g} / \mathrm{ml}$ for R $4 \Delta 22 \mathrm{~B}$ lysogen and $100 \mu \mathrm{g} / \mathrm{ml}$ for R4A22B-tsr 1 lysogen. The MIC value for R4422B-tsr1 lysogen is almost equivalent to that of $S$. parvulus carrying the pIJ365 plasmid. As the pIJ365 is a multi-copy type $\left.{ }^{6}\right)$ the thiopeptin resistant level in the R4A22B-tsr1 lysogen seems to be quite high if the genome number of R4 phage in the lysogenic state is equal to that of the host chromosome. This is also the case in actino-phage $\phi \mathrm{C} 31 .{ }^{7)}$

Biological and physical characterization of R4 phage derivatives described in this and previous papers $^{1 \sim 3)}$ are summarized in Table IV.

Acknowledgments. This work was partly supported by a Grant-in-Aid for Scientific Research from the Ministry of Education, Science and Culture of Japan.

\section{REFERENCES}

1) T. Isogai, H. Takahashi and H. Saito, J. Gen. Appl. Microbiol., 27, 373 (1981).

2) H. Takahashi, T. Isogai, T. Morino, H. Kojima and H. Saito, Proc. of IVth International Symp. on Genetics of Industrial Microorganisms, 1982, p. 61.

3) T. Morino, T. Isogai, H. Kojima, H. Takahashi and H. Saito, Agric. Biol. Chem., 47, 1873 (1983).

4) B. G. Williams and F. R. Blattner, J. Virology, 29, 
555 (1979).

5) T. Isogai, H. Takahashi and H. Saito, Agric. Biol. Chem., 44, 2435 (1980).

6) T. Kieser, D. A. Hopwood, H. M. Wright and C. J. Thompson, Mol. Gen. Genet., 185, 223 (1982).
7) K. F. Chater, C. J. Bruton, A. King and J. F. Suarez, Gene, 19, 21 (1982).

8) D. I. Ish-Horowicz and J. E. Burke, Nucleic Acids Res., 9, 2989 (1981). 